\title{
Characterization of a Fluorescent Probe for Imaging Nitric Oxide
}

\author{
Yohannes T. Ghebremariam ${ }^{a}$ Ngan F. Huang ${ }^{c}$ Swetha Kambhampati ${ }^{c}$ \\ Katharina S. Volz ${ }^{c}$ Gururaj G. Joshi ${ }^{b}$ Eric V. Anslyn ${ }^{b}$ John P. Cooke ${ }^{a}$ \\ ${ }^{a}$ Department of Cardiovascular Sciences, Houston Methodist Research Institute, and ${ }^{b}$ Department of Chemistry and \\ Biochemistry, University of Texas, Austin, Tex., and 'Stanford Cardiovascular Institute, Stanford, Calif., USA
}

\section{Key Words}

Asymmetric dimethylarginine - Endothelial cells .

Fluorescent $\mathrm{NO}_{550}$ probe $\cdot$ Nitric oxide $\cdot$ Nitric oxide imaging $\cdot$ Nitric oxide synthase

\begin{abstract}
Background: Nitric oxide (NO), a potent vasodilator and anti-atherogenic molecule, is synthesized in various cell types, including vascular endothelial cells (ECs). The biological importance of NO enforces the need to develop and characterize specific and sensitive probes. To date, several fluorophores, chromophores and colorimetric techniques have been developed to detect $\mathrm{NO}$ or its metabolites $\left(\mathrm{NO}_{2}\right.$ and $\mathrm{NO}_{3}$ ) in biological fluids, viable cells or cell lysates. Methods: Recently, a novel probe $\left(\mathrm{NO}_{550}\right)$ has been developed and reported to detect NO in solutions and in primary astrocytes and neuronal cells with a fluorescence signal arising from a nonfluorescent background. Results: Here, we report further characterization of this probe by optimizing conditions for the detection and imaging of NO products in primary vascular ECs, fibroblasts, and embryonic stem cell- and induced pluripotent stem cell-derived ECs in the absence and presence of pharmacological agents that modulate NO levels. In addition, we studied the stability of this probe in cells over
\end{abstract}

time and evaluated its compartmentalization in reference to organelle-labeling dyes. Finally, we synthesized an inherently fluorescent diazo ring compound $\left(\mathrm{AZO}_{550}\right)$ that is expected to form when the nonfluorescent $\mathrm{NO}_{550}$ reacts with cellular NO, and compared its cellular distribution with that of $\mathrm{NO}_{550}$. Conclusion: $\mathrm{NO}_{550}$ is a promising agent for imaging $\mathrm{NO}$ at baseline and in response to pharmacological agents that modulate its levels.

(c) 2013 S. Karger AG, Basel

\section{Introduction}

Endothelium-derived nitric oxide (NO) is a potent signaling molecule that is critically involved in maintaining metabolic and cardiovascular homeostasis [1-3]. In addition to its role as a potent endogenous vasodilator, we and others have shown that NO plays a key role in regulating vascular smooth muscle cell growth, as well as the interaction of the vessel wall with circulating blood elements. Because NO suppresses the expression of endothelial adhesion molecules and chemokines, it reduces endothelial adhesiveness for monocytes [4-6]. Furthermore, NO suppresses platelet reactivity $[7,8]$ and vascular smooth muscle cell proliferation $[9,10]$. Because NO suppresses

\section{KARGER}

E-Mail karger@karger.com

www.karger.com/jvr
(C) 2013 S. Karger AG, Basel

1018-1172/13/0511-0068 $\$ 38.00 / 0$
Dr. John P. Cooke

Department of Cardiovascular Sciences

Center for Cardiovascular Regeneration

Methodist Hospital Research Institute, Houston, TX 77030 (USA)

E-Mail jpcooke@tmhs.org 
key processes in vascular lesion formation, enhancement of NO synthesis is associated with resistance to atherogenesis and myointimal hyperplasia [11-13]. By contrast, pharmacological or genetic suppression of NO synthesis is associated with reduced vascular compliance [14] and an acceleration of vascular disease in preclinical models $[15,16]$. Notably, enhancement of NO synthesis is associated with insulin sensitivity [17] whereas genetic knockdown of endothelial NO synthesis increases insulin resistance [18]. These preclinical studies suggest that endothelium-derived NO is critical for vascular health. Indeed, accumulating evidence from epidemiological studies indicate that humans with impaired endothelial NO synthase (eNOS) activity are at increased risk for major adverse cardiovascular events and mortality [19-21].

It is, therefore, due to this essential role of NO in biological systems and cardiovascular health that substantial amount of research has focused on developing methods to differentially detect and quantify its concentration in biological samples. Some of these methods include the Griess colorimetric assay, which measures total NO (as $\mathrm{NO}_{3}$ and $\mathrm{NO}_{2}$ ) in various biological fluids and cell culture media; electrochemical measurement using a currentbased electrode system [22]; electron paramagnetic resonance spectrometry by complexing $\mathrm{NO}$ with chemicals such as iron and hemoglobin [23]; an NO-sensitive porphyrin-based electrode [24]; a chemiluminescent technique which quantifies $\mathrm{NO}$ following its reaction with luminol [25]; dual-photon microscopy [26], and an HPLCbased system [27]. However, the colorimetric technique detects NO indirectly, lacks real-time measurement in viable cells and only detects micromolar concentrations of the molecule, and many of the other techniques generally require instrumentation and expertise that are not readily available in many laboratories. Meanwhile, small molecule-based fluorescent techniques that use cell-permeable probes have been developed to quantify NO in viable cells and in vivo. Some of these probes include diaminobenzene-based fluorophores such as diaminofluoresceins (DAFs) [28], diaminonaphthalene (DAN) [29, 30], diaminorhodamine (DAR-4M) [30], diaminoanthraquinone [31]; chemical element-based probes such as the boron-based chromophore BODIPY [32, 33], copperbased fluorophore (CuFL) [34] and a lanthanide-based time-resolved luminescence probe [35]; synthetic dyebased fluorophores such as cyanine-based probes (DACs) [36], and others such as the nanocrystal-based quantum dots (QDs) [37] and carbon nanotube-based sensors (SWNTs) [38] (table 1). Their sensitivity to NO at nanomolar concentrations, ease of use, real-time measure- ment, and their application in living cells have made these fluorescent techniques a premium choice for the detection and imaging of NO in mammalian cells. However, high $\mathrm{pH}$ dependence, high background signal due to side reactions with other nitrogen/oxygen species, and fluorescence quenching confound the measurements obtained by many of these fluorophores. In this study, we evaluated the use of a new probe $\left(\mathrm{NO}_{550}\right)$ [39] to detect signals associated with $\mathrm{NO}$ levels produced by vascular cells (fig. 1). Chemically, the nonfluorescent $\mathrm{NO}_{550}$ reacts with oxidized $\mathrm{NO}$ to form a fluorescent product $\left(\mathrm{AZO}_{550}\right)$. The preliminary study by Yang et al. [39] provided important insights about the $\mathrm{NO}_{550}$ probe. However, the study did not address the possibility of imaging $\mathrm{NO}$ in nonneuronal cells, e.g. vascular ECs and fibroblasts. In addition, their study was limited in examining the ability of the probe to sense changes in NO levels as a result of pharmacological manipulation of pathways that are major sources of NO, including the NOS and xanthine oxidoreductase (XOR) pathways. Moreover, the study by Yang et al. [39] did not address the biochemical stability of the $\mathrm{NO}_{550}$ probe in cells. Accordingly, we designed a study to test the following hypotheses: (1) the $\mathrm{NO}_{550}$ probe will be able to detect NO produced by a variety of cell types in response to pharmacological agents that modulate NO; (2) $\mathrm{NO}_{550}$ will be able to distribute in cellular compartments in line with NO localization and comparable to commercially available NO detection dyes such as DAF-FM diacetate, and (3) $\mathrm{NO}_{550}$ is a chemically stable probe when loaded to cells and may be useful to study NO kinetics over time.

\section{Materials and Methods}

Primary human microvascular endothelial cells (HMVECs; p3), EC maintenance media (EBM2), and growth supplements were purchased from Lonza (Walkersville, Md., USA). Dulbecco's modified Eagle's medium (catalog No. 11995) was purchased from Invitrogen (Grand Island, N.Y., USA). Human foreskin (BJ) fibroblasts were purchased from ATCC Bioresource Center (Manassas, Va., USA) and human dermal fibroblasts (HUF) were obtained from the laboratory of Dr. Renee Reijo Pera (Stanford University). $\mathrm{NO}$ probes $\left(\mathrm{NO}_{550}\right.$ and $\left.\mathrm{AZO}_{550}\right)$ were from the laboratory of Dr. Eric Anslyn (University of Texas at Austin) and were dissolved in stock DMSO (Sigma D2650) to obtain a stock concentration of 10 $\mathrm{mM}$ prior to diluting in media to final concentrations of 20 $\left(\mathrm{AZO}_{550}\right)$ and $50-100 \mu \mathrm{M}\left(\mathrm{NO}_{550}\right)$. The final DMSO concentration was $0.2 \%$ for $\mathrm{AZO}_{550}$ and $0.5-1 \%$ for $\mathrm{NO}_{550}$. DAF-FM diacetate was purchased from Molecular Probes (Eugene, Oreg., USA; cata$\log$ No. D-23844) and was dissolved in stock DMSO to a $5-\mathrm{mM}$ concentration as recommended. The organelle-labeling dyes LysoTracker and ER-Tracker were purchased from Invitrogen (cata- 
$\log$ Nos. L7528 and E34250, respectively) and were diluted in $1 \mathrm{mM}$ stock solution to the desired final concentration in fresh media. $\mathrm{N}^{\mathrm{G}}$-nitro-L-arginine methyl ester (L-NAME), allopurinol, TNF- $\alpha$, 2-phenyl-4,4,5,5-tetramethylimidazoline-1-oxyl 3-oxide (PTIO), and a toxicity assay kit were purchased from Sigma (St. Louis, Mo., USA); a Griess assay kit for NO quantification was from Assay Designs (Ann Arbor, Mich., USA); RT-PCR primers were from Applied Biosystems (Foster City, Calif., USA), and the anti-eNOS antibody was purchased from BD Transduction Laboratories (San Jose, Calif., USA; catalog No. 610296).

Statistical tests between two groups were performed using unpaired $t$ test of the mean values and expressed as means \pm SEM. Multiple group comparison was performed using one-way ANOVA followed by the Bonferroni post hoc test. Data were considered statistically significant at $\mathrm{p}<0.05$.

\section{NO Imaging Assay}

HMVECs were seeded in $75-\mathrm{cm}^{2}$ tissue culture flasks containing growth factor-fortified (including $5 \%$ fetal calf serum) EBM2 media and incubated at $37^{\circ} \mathrm{C} / 5 \% \mathrm{CO}_{2}$ to the desired degree of confluency. Once ready, the conditioned media were aspirated and the cells were briefly washed with PBS. Subsequently, the cells were exposed to the $\mathrm{NO}_{550}$ probe (premixed with fresh media) to a final concentration of $50,60,75$, or $100 \mu \mathrm{M}$ for various time points (1, 2, 3, 4, and $24 \mathrm{~h}$ ). For kinetics studies, cells were imaged under a fluorescent microscope by removing the plates from the incubator at predetermined time points. For an endpoint study, the cells were exposed to a defined concentration of $\mathrm{NO}_{550}(60-75 \mu \mathrm{M})$, and Hoechst 33342 (Sigma B2261; $5 \mu \mathrm{g} / \mathrm{ml}$ final concentration) was used to stain nuclei. The same procedure was followed to expose cells to chemically synthesized $\mathrm{AZO}_{550}(20 \mu \mathrm{M})$ or the NO imaging agent DAF-FM diacetate $(1 \mu \mathrm{M})$, and cells were imaged under the same excitation/emission spectra as $\mathrm{NO}_{550}$. Background fluorescence was studied by incubating $\mathrm{NO}_{550}$ with the same media in the absence of cells and was followed over time.

\section{Image Acquisition and Analysis}

Images were captured at the indicated time points under the same image acquisition settings (with the exception of the 24-hour image set in fig. $2 \mathrm{~g}$, where the exposure time for all the samples at that time point was reset to minimize image saturation) at excitation/emission spectra of $488 / 519 \mathrm{~nm}$ for $\mathrm{NO}_{550} / \mathrm{AZO}_{550} / \mathrm{DAF}-\mathrm{FM}$ diacetate and at 358/461 $\mathrm{nm}$ for the nuclear Hoechst staining using a standard inverted fluorescence microscope (Nikon Eclipse TE 2000-U) equipped with SPOT (2.2.1/RTPS-IN; Diagnostic Instruments, Sterling Heights, Mich., USA) and QImaging (RETIGA2000R FAST) cameras. The exposure time for the color images was set using SPOT Advanced (Diagnostic Instruments;) and the black/white acquisition parameters were set using the QCapture Pro software (QImaging, Surrey, B.C., Canada). Finally, regions of interest were placed over each of the individual cells in the field of view, and the average fluorescence value was analyzed using ImageJ software (National Institutes of Health, NIH) [40] under the same settings. In each case, the average background at zero time point was used to subtract from the average fluorescence value for the whole time series due to minimal changes in background fluorescence over time as described in the Results section below.

All images were taken at $\times 20$ objective magnification $(0.45 \mathrm{nu}-$ merical aperture) unless stated otherwise. All the scale bars are 50 or $100 \mu \mathrm{m}$ unless indicated otherwise.

\section{Enhancement or Inhibition of NO Levels}

ECs were exposed to agents that negatively (L-NAME/allopurinol: final concentration from $100 \mu \mathrm{M}$ to $1 \mathrm{mM}$ each; NO scavenger: PTIO at a final concentration of $10-100 \mu \mathrm{M}$ ) or positively [acetylcholine (ACh; $10 \mu \mathrm{M})$, the NO donor S-nitroso-N-acetyl-DLpenicillamine (SNAP; $10 \mu \mathrm{M})$ or TNF- $\alpha(10 \mathrm{ng} / \mathrm{ml})]$ influence intracellular NO levels. The chemicals were dissolved in stock DMSO to $100 \mathrm{mM}$ and then further diluted in PBS as needed while recombinant human TNF- $\alpha$ was dissolved in PBS containing 1\% BSA to $1 \mu \mathrm{g} / \mathrm{ml}$ stock concentration and was further diluted in PBS. The diluted reagents or diluted DMSO control solution were then added to fresh media and prewashed adherent cells cultured in 12well plates were exposed to these agents either alone or in combination (such as allopurinol + L-NAME + NO scavenger) at the stated final concentrations. Subsequently, $\mathrm{NO}_{550}$ was added to image the changes in NO levels in response to these agents. Images were captured at various time points during the treatment course. Image analyses were performed as described above. Meanwhile, the standard Griess assay was used to quantify total NO in cells similarly treated with vehicle, L-NAME/allopurinol, PTIO or the L-NAME/allopurinol/PTIO combination.

\section{Compartmentalization of $\mathrm{NO}_{550}$}

In order to assess the intracellular compartmentalization of $\mathrm{NO}_{550}$, we used cell-permeant organelle-selective fluorescent probes to label the lysosomes (using the LysoTracker Red DND-99 dye) and the endoplasmic reticulum (ER; using the ER-Tracker Red dye). ECs were loaded with $\mathrm{NO}_{550}(60 \mu \mathrm{M}$ final concentration) for $30 \mathrm{~min}$ and then LysoTracker or ER-Tracker dyes were added to the cells at the preoptimized final concentrations $(0.5$ and $1 \mu \mathrm{M}$, respectively) for these cells. The loaded cells were incubated at $37^{\circ} \mathrm{C} / 5 \% \mathrm{CO}_{2}$ for additional $2-3 \mathrm{~h}$. Finally, the cells were incubated with Hoechst for $5 \mathrm{~min}$ to stain the nuclei. Images were acquired at excitation/emission wavelengths of 358/461, 488/519, and 595/615 $\mathrm{nm}$ for DAPI, $\mathrm{NO}_{550}$ and Lyso-/ER-Tracker dyes, respectively, as described above and were merged for colocalization studies.

\section{Toxicity Assay}

To assess the degree of cellular toxicity of the $\mathrm{NO}_{550}$ probe, ECs were seeded on 12-well plates overnight and then exposed to various concentrations of the probe $(60-100 \mu \mathrm{M})$ or vehicle for $4 \mathrm{~h}$. The cells were washed and dissociated by Accutase solution (Sigma, catalog No. A6964) treatment, pelleted by centrifugation at $500 \mathrm{~g}$ for $3 \mathrm{~min}$ and then the viable cells were counted in replicates using an automated cell counter (TC10; Bio-Rad, Hercules, Calif., USA) after staining with trypan blue $(0.4 \%)$ to exclude dead cells. In addition, cytotoxicity was also assessed using an ELISA-based lactate dehydrogenase (LDH) leakage assay as recommended by the supplier. In brief, ECs were seeded at a density of $3 \times 10^{4}$ cells/well in 12 -well plates overnight and then washed and exposed to $\mathrm{NO}_{550}$ $(60-100 \mu \mathrm{M})$ or vehicle control for $4 \mathrm{~h}$ prior to harvesting the conditioned media. The supernatant was clarified by centrifugation at $250 \mathrm{~g}$ for $4 \mathrm{~min}$ and $25 \mu \mathrm{l}$ of each sample, including blank media, were transferred into a 96-well plate in duplicate for cytotoxicity assays. Absorbance, proportional to the amount of $\mathrm{LDH}$ released, was measured using a plate reader (M1000; Tecan, Männedorf, Switzerland) at $490 \mathrm{~nm}$. The background absorbance (measured at $690 \mathrm{~nm}$ ) was subtracted from the respective absorbencies at 490 $\mathrm{nm}$ and the data (indicating cell membrane integrity) were analyzed using GraphPad Prism (La Jolla, Calif., USA). 
Fig. 1. Schematic diagram illustrating the regulation of $\mathrm{NO}$ production and reactivity to the $\mathrm{NO}_{550}$ probe to generate a fluorescent $\mathrm{AZO}_{550}$ product.

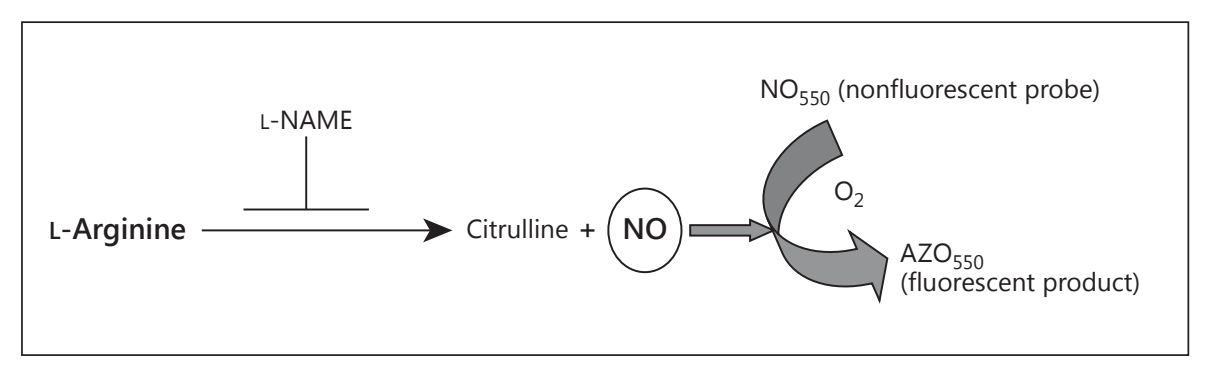

Comparison of $\mathrm{NO}_{550}$ with DAF-FM Diacetate

$\mathrm{NO}_{550}$ was compared with the commercially available DAF-FM diacetate fluorophore for the detection and imaging of intracellular NO in primary ECs. In brief, HMVECs were cultured and the detection of $\mathrm{NO}$ using the $\mathrm{NO}_{550}$ probe was performed as described above. In parallel experiments, HMVECs were incubated with $1 \mu \mathrm{M}$ of freshly diluted (from DMSO stock) DAF-FM diacetate at $37^{\circ} \mathrm{C} / 5 \% \mathrm{CO}_{2}$ for $20 \mathrm{~min}$ as recommended by the supplier. Excess probe was removed by rinsing and the cells were switched to fresh media or PBS prior to imaging.

\section{RT-PCR and Western Blot Analyses of eNOS}

Baseline gene and protein expression profiling of eNOS in ECs, human induced pluripotent stem cells (hiPSCs) and hiPSC-derived ECs were performed by RT-PCR and Western blot, respectively. The gene expression study was performed as described previously $[41,42]$. For the Western blot study, $6 \mu \mathrm{g}$ of total protein were transferred into Eppendorf tubes and $1 \times$ LDS buffer and reducing agent were added to the samples prior to boiling the mixtures. The samples were resolved on a $4-12 \%$ precast gel at $125 \mathrm{~mA}$ for $2 \mathrm{~h}$. The samples were then transferred to nitrocellulose membrane using a semidry iBlot (Invitrogen) system and the blot was blocked with $5 \%$ nonfat milk (in $0.1 \%$ TBST) for $1 \mathrm{~h}$ at room temperature (RT). Subsequently, the blot was incubated with 1:2,500-diluted mouse anti-eNOS primary antibody at $4^{\circ} \mathrm{C}$ overnight. The next day, the blot was washed with $0.1 \%$ TBST $(4 \times$ 5 min each wash) and incubated with HRP-conjugated goat antimouse secondary antibody (1:5,000 diluted; GE Healthcare, Little Chalfont, UK, catalog No. NA931V) for $1 \mathrm{~h}$ at RT. Finally, the blot was washed, ECL Plus detection reagent was added for $5 \mathrm{~min}$ at $\mathrm{RT}$, and the film was developed using an automated film processor. eNOS protein $(140 \mathrm{kDa})$ expression was normalized to human $\beta$-actin housekeeping protein $(42 \mathrm{kDa})$ by stripping the blot and reprobing it with rabbit anti-actin antibody (1:1,500 diluted; Sigma, catalog No. A2066).

Differentiation of ESCs and iPSCs into ECs

Mouse ESCs (mESCs) and human iPSCs were differentiated into ECs and purified by fluorescence-activated cell sorting using the EC markers CD144 (for mESC-derived ECs) [41] and CD31 (for hiPSC-derived ECs) [42] as we have previously described. The hiPSC-derived ECs were maintained using a similar protocol and reagents used for the maintenance of primary ECs. The mESCderived ECs were maintained in growth medium containing alpha minimum Eagle's medium, fetal bovine serum, penicillin/streptomycin, and $\beta$-mercaptoethanol [41].

\section{Results}

$\mathrm{NO}_{550}$ : Mechanism of Detecting $\mathrm{NO}$

Oxidation reaction of the nonfluorescent $\mathrm{NO}_{550}$ probe with $\mathrm{NO}$ generated a fluorescent azo compound $\left(\mathrm{AZO}_{550}\right.$; fig. 1) presumably through the stepwise generation of nitrosamine- and hydroxyhydrazine-derived compounds as previously described [39].

\section{Detection of NO: Dependency on $\mathrm{NO}_{550}$ Probe \\ Concentration and Incubation Time}

The ability of $\mathrm{NO}_{550}$ to detect oxidized $\mathrm{NO}$ in ECs was studied over a range of probe concentrations. We found that at a final probe concentration of $50 \mu \mathrm{M}$, a modest intracellular fluorescence signal was observed as early as 60 min after addition of the probe and was progressively enhanced when the probe concentration or incubation time was increased (fig. 2). Importantly, despite the increase in intracellular fluorescence intensity upon incubation of the probe with the cells over time, there was negligible change in background fluorescence when the probe was incubated with media only in the absence of cells (online suppl. fig. S1; for all online supplentary material, see www.karger.com/doi/10.1159/000356445). When ECs were incubated with the $\mathrm{NO}_{550}$ probe at concentrations $>100 \mu \mathrm{M}$, cytotoxicity and/or enhanced background fluorescence was observed (data not shown).

In addition, the probe was also successfully used to image oxidation products of $\mathrm{NO}$ in primary fibroblasts, and ESC- as well as iPSC-derived ECs (online suppl. fig. S2). Interestingly, hiPSCs showed NO production preferentially at the border of colonies (online suppl. fig. S3); these border cells are known to be susceptible to spontaneous differentiation compared with cells in the center of colonies. Such cells may have begun to express functional NOS [43]. Our RT-PCR and Western blot data also show that only the differentiated cells (ECs and iPSC-derived ECs) but not the iPSCs express eNOS (online suppl. fig. S4). 

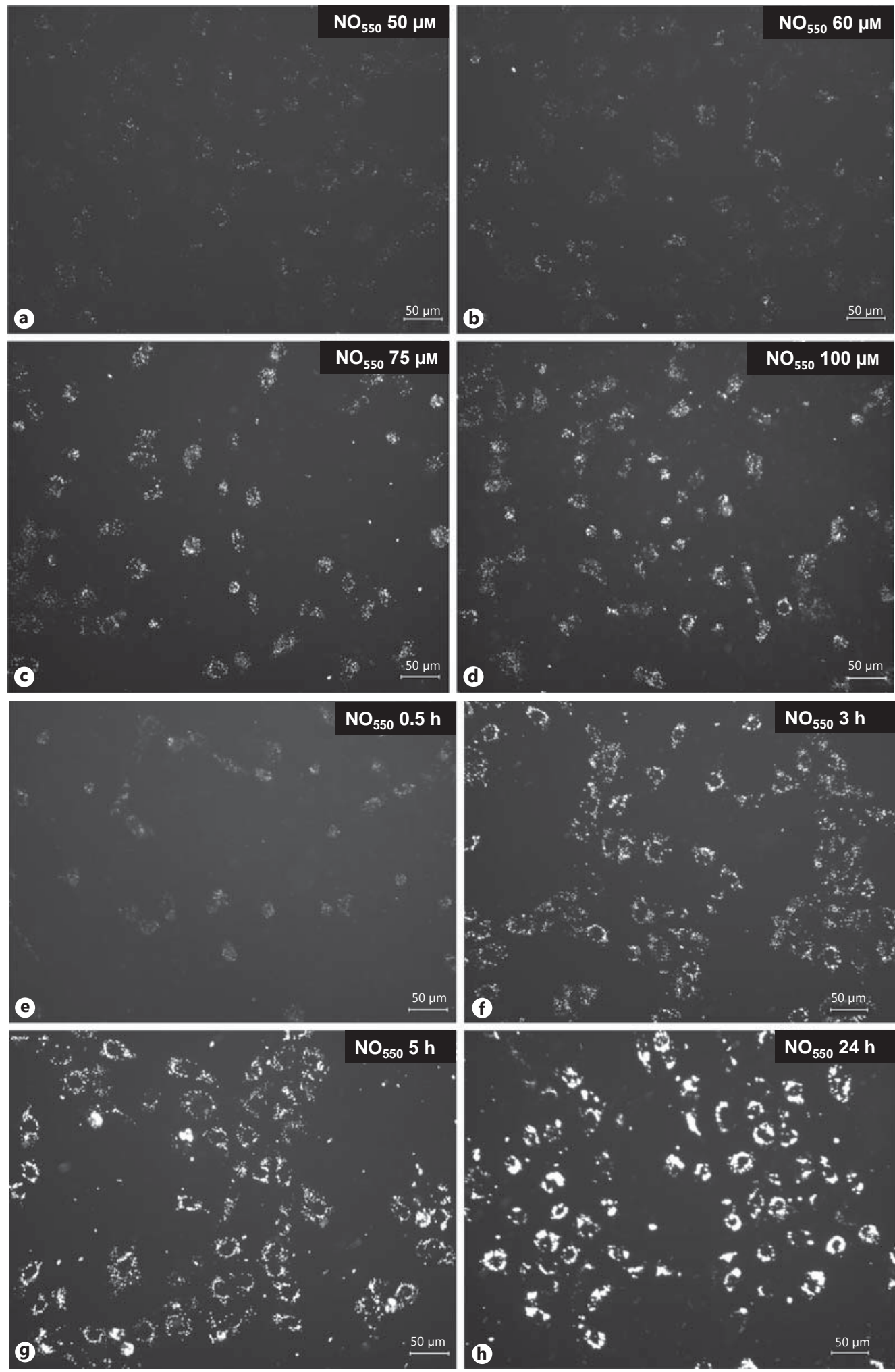

Fig. 2. a-d Fluorescence microscopy demonstrating the imaging of NO produced by HMVECs over a range of probe concentrations $2 \mathrm{~h}$ after loading the cells with 50 (a), 60 (b), 75 (c) and 100 $\mu \mathrm{M}(\mathbf{d})$ of $\mathrm{NO}_{550}$ probe. $\mathbf{e}-\mathbf{h}$ Fluorescence microscopy showing the detection of intracellular NO generated by HMVECs over time after loading the cells with $75 \mu \mathrm{M}$ of $\mathrm{NO}_{550}$ probe for $30 \mathrm{~min}(\mathbf{e})$, and $3(\mathbf{f}), 5(\mathbf{g})$ and $24 \mathrm{~h}(\mathbf{h})$. 


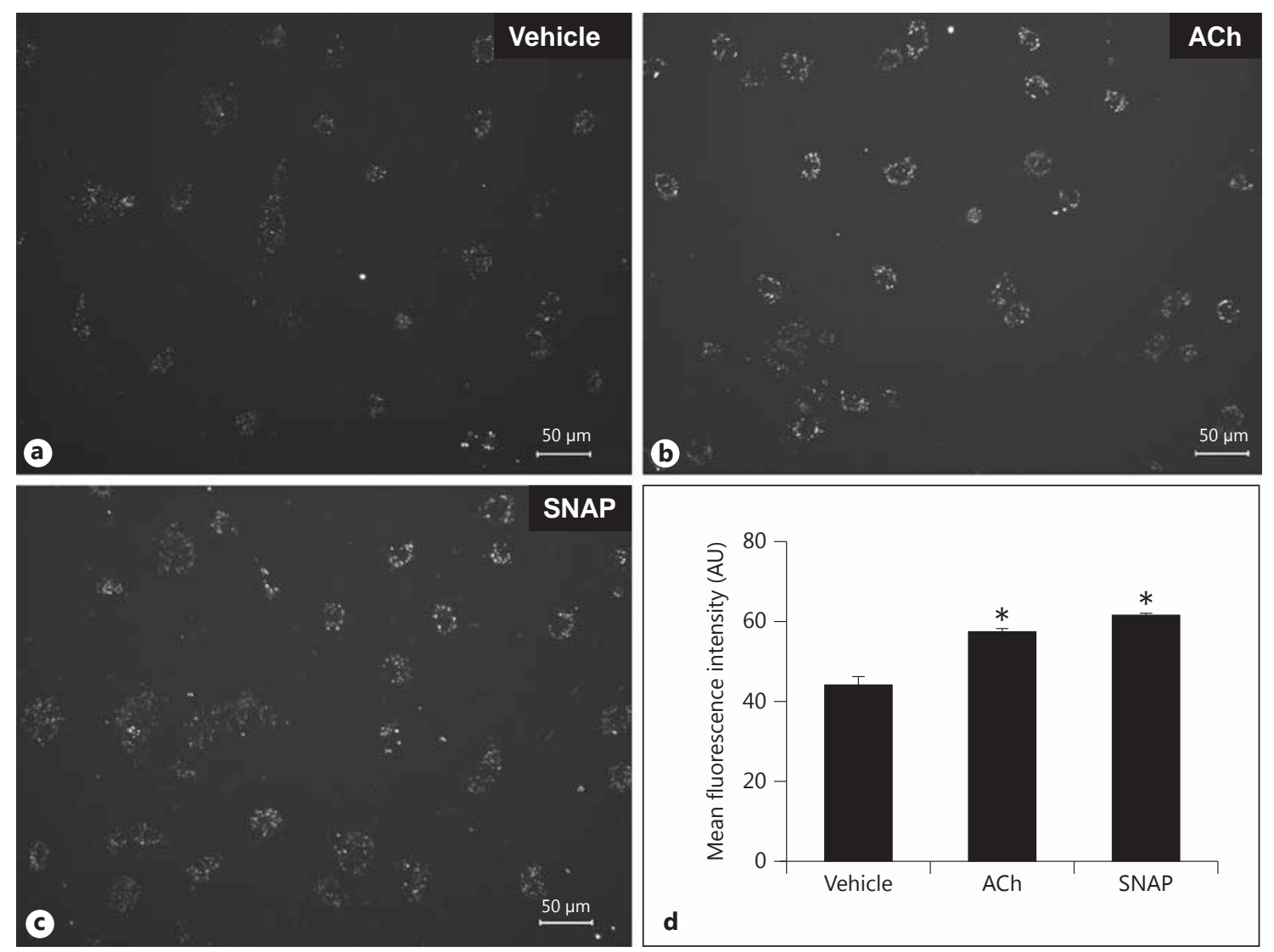

Fig. 3. Stimulation of HMVECs with DMSO vehicle (a) or pharmacological agents: ACh $(10 \mu \mathrm{M}$; b) or the NO donor SNAP $(10 \mu \mathrm{M} ; \mathbf{c})$. NO $550(60 \mu \mathrm{M})$ was added at the time of treatment with these agents. d Fluorescence intensity quantification is expressed as arbitrary units (AU; means $\pm S E M ;{ }^{*} p<0.05$ vs. vehicle).

\section{Stimulation or Inhibition of NO Production}

In addition to imaging physiological levels of oxidized NO produced intracellularly, cells were also treated with various agents that promote or inhibit NO levels. Treatment of ECs with ACh (which activates NOS) and the NO donor SNAP (which releases NO) increased fluorescence intensity (fig. 3). Treatment of the cells with inhibitors of NO production such as L-NAME and allopurinol blunted the fluorescent signal compared to the vehicle control (fig. 4) consistent with the hypothesis that the probe was detecting NOS- and XOR-dependent production of NO. However, the fluorescent signal was only completely antagonized when the NO radical scavenger PTIO [44, 45] was added (fig. 4c), suggesting the existence of alternative NO sources that are insensitive to NOS/XOR inhibition. This finding was corroborated by an established Griess assay quantifying NO levels under these conditions (fig. 5). Similarly, we found that cytokine-mediated induction of NO signaling could be effec- tively abolished by cotreatment with the NO scavenger PTIO (online suppl. fig. S5).

\section{Compartmentalization of $\mathrm{NO}_{550}$}

We studied the localization of $\mathrm{NO}_{550}$ in intracellular compartments using organelle-labeling fluorescent dyes. Simultaneous labeling of the nuclei and acidic organelles such as the lysosomes in $\mathrm{NO}_{550}$-stained cells revealed that despite its vesicle-like staining, $\mathrm{NO}_{550}$ only partly appears to emanate from this compartment (fig. 6). Labeling of the ER with a fluorescent dye that binds to sulfonylurea receptors (subunits of the ATP-sensitive $\mathrm{K}^{+}$channels that are abundantly expressed in the ER) indicated that the uptake and/or trafficking of $\mathrm{NO}_{550}$ was impaired in the majority of cells stained with the ER-Tracker dye (fig. 6).

\section{Cytotoxicity of $\mathrm{NO}_{550}$}

We estimated the degree of in vitro cytotoxicity of the $\mathrm{NO}_{550}$ probe by counting viable cells and biochemically 

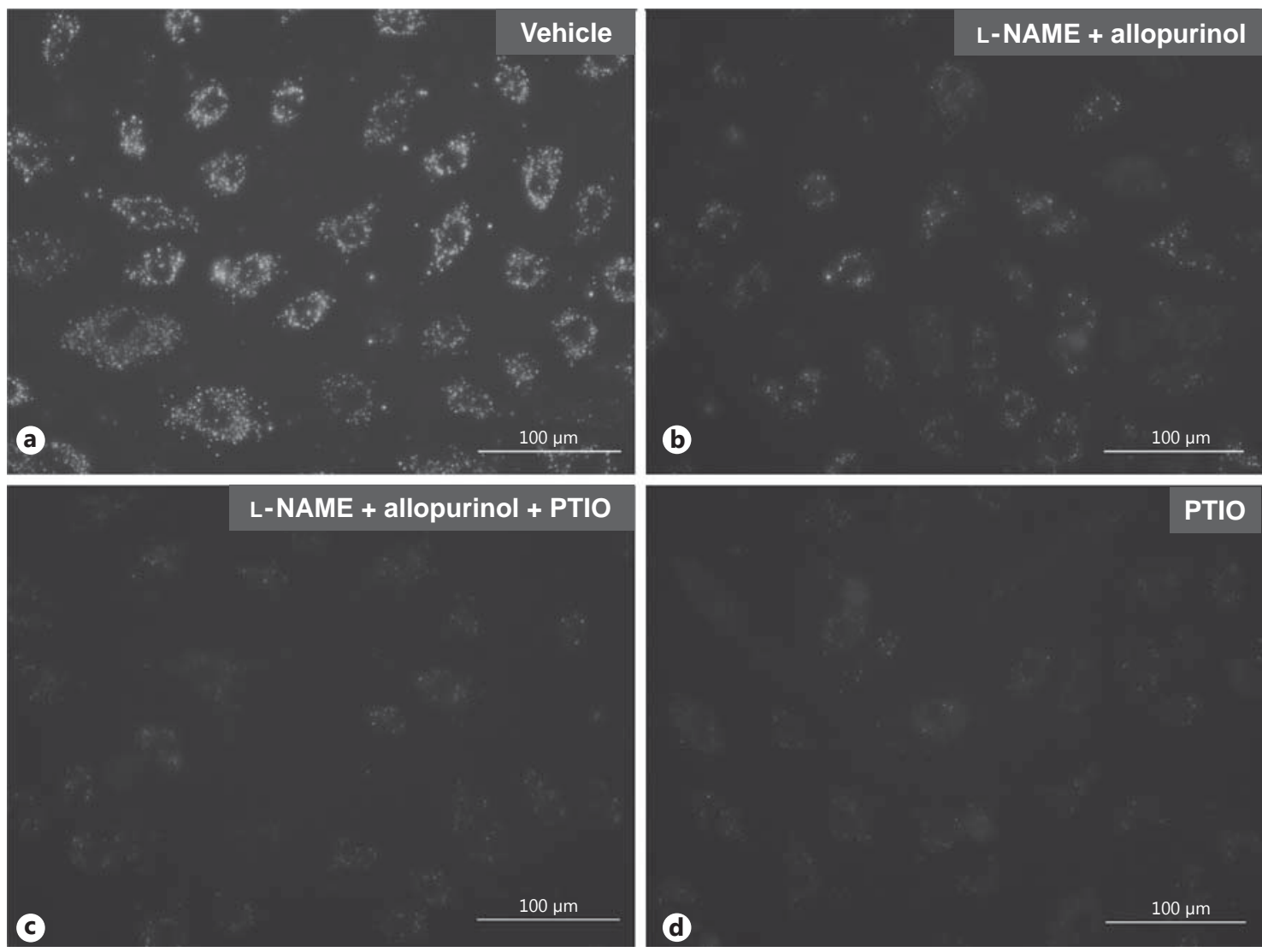

Fig. 4. Treatment of HMVECs with NOS/XOR inhibitors and NO scavenger. a Vehicle. b L-NAME + allopurinol $(100 \mu \mathrm{M}$ each for $24 \mathrm{~h})$. c L-NAME + allopurinol + PTIO. d PTIO (10 $\mu \mathrm{M}$ for $1 \mathrm{~h})$. The final concentration of $\mathrm{NO}_{550}$ loaded was $75 \mu \mathrm{M}$.

by an ELISA-based LDH release assay. These studies revealed that $\mathrm{NO}_{550}$ could be used to image $\mathrm{NO}$ produced by primary vascular ECs when cells are incubated at relatively high probe concentration for at least $4 \mathrm{~h}$ (online suppl. fig. S6). Similarly, ATP production studies following the loading of astrocytes and a neuronal cell line with $\mathrm{NO}_{550}$ also found no differences in the metabolic activity of $\mathrm{NO}_{550}$-loaded cells compared to controls [39].

\section{Imaging of $\mathrm{NO}$ with $\mathrm{NO}_{550}$ Compared to DAF-FM}

Our direct comparison of $\mathrm{NO}_{550}$ with a commercially available and relatively optimized fluorophore for NO imaging, DAF-FM diacetate, indicated that while $\mathrm{NO}_{550}$ has minimal extracellular fluorescence, DAF-FM diacetate produced very bright fluorescence intensity even when used at 75-fold lower concentration (fig. 7). Meanwhile, our attempt to reduce the background signal and nuclear entry associated with DAF-FM diacetate by varying the incubation temperature (from 37 to $4^{\circ} \mathrm{C}$ ), incuba- tion time (from 60 to $10 \mathrm{~min}$ ), and probe concentration was not successful. These results suggested that some inherent nonspecific reaction(s) and/or spontaneous removal of the acetyl groups in the starting reagent might have yielded the relatively more fluorescent intermediate product, DAF-FM [46].

On the other hand, despite its weaker fluorescence intensity, the signal produced by the $\mathrm{NO}_{550}$ probe was punctate and cytoplasmic in its distribution, consistent with the extranuclear localization and particulate association of NOS (fig. 7; online suppl. fig. S7).

\section{Discussion}

The NO pathway is centrally involved in endothelial homeostasis as well as many other cellular processes. As a messenger involved in several of these physiological and pathological conditions, NO is a profoundly important 


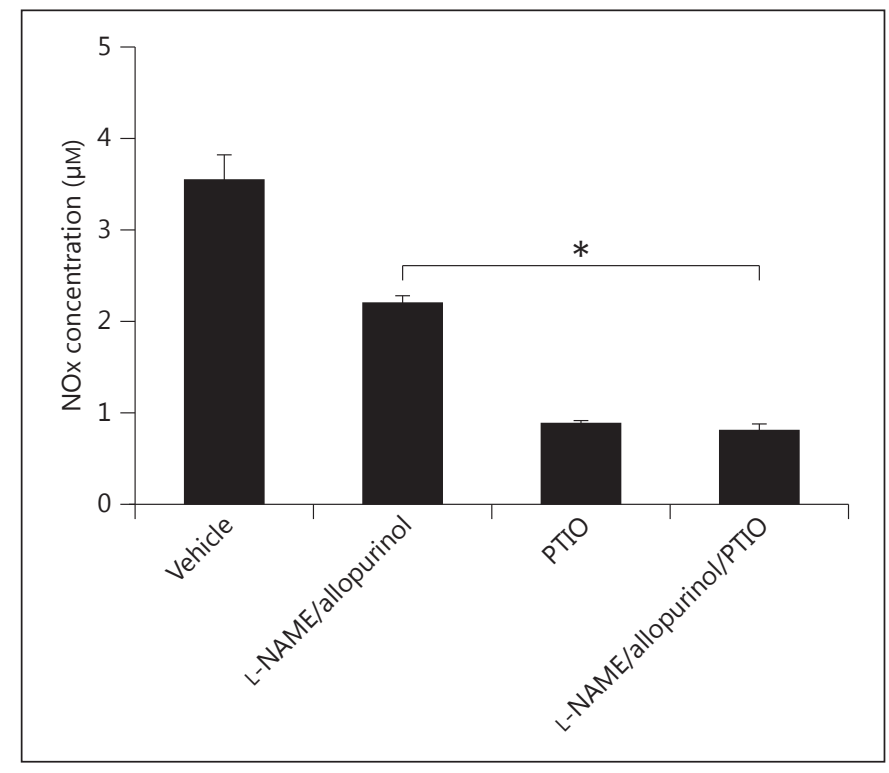

Fig. 5. The effect of pharmacological agents on NO production. HMVECs were treated with vehicle, L-NAME/allopurinol $(100 \mu \mathrm{M}$ each; $24 \mathrm{~h})$, PTIO (10 $\mu \mathrm{M} ; 1 \mathrm{~h})$ or the L-NAME/allopurinol/PTIO combination. Total nitrite (NOx) was measured using the Griess reaction. Means \pm SEM from duplicate experiments. ${ }^{*} \mathrm{p}<0.05$ vs. vehicle control.

signaling molecule. Unfortunately, due to the exquisitely short half-life of NO [47], lack of selective reagents and robust techniques to directly measure its concentration, and the requirement of specialized instrumentation by some of the developed techniques, the degree and distribution of intracellular NO under basal and stimulated conditions has been a challenge. In addition, since many of the reported fluorophores permeate into the nuclear membrane of cells, they likely interfere with DNA replication and cell survival, limiting longer kinetic studies when the cells are loaded with these imaging agents. Recently, Yang et al. [39] developed and characterized a novel imaging probe $\left(\mathrm{NO}_{550}\right)$ by applying a technique that yields a fluorescent product $\left(\mathrm{AZO}_{550}\right)$ from the oxidative reaction of a nonfluorescent probe $\left(\mathrm{NO}_{550}\right)$ with $\mathrm{NO}$. The probe was able to react with bubbled $\mathrm{NO}$ gas in solution and with oxidation products of endogenously produced NO in neuronal cells and astrocytes while showing no $\mathrm{pH}$ dependency over a biologically relevant range ( $\mathrm{pH} 4.5-9)$. In the present study, $\mathrm{NO}_{550}$ is further characterized by demonstrating its application in the imaging of $\mathrm{NO}$ in vascular ECs. Functionally, we described the utility of this probe to perform kinetic studies by demonstrating the real-time imaging of NO derivatives in cells incubated with various concentrations of the probe over a period of time as well as in response to various pharmacological agents that enhance or inhibit NO production. However, there are some discrepancies between our findings and those of Yang et al. [39] in that the localization and distribution pattern of the fluorescent signal appears to be distinct between the studies. It is possible that such differences might have arisen as a result of the species from which the cells were derived (mouse vs. human cells), developmental stages of the cells used (neonatal vs. adult), the cell types studied (astrocytes vs. vascular ECs), and the dominant NOS isoforms expressed by these cells (neuronal NOS vs. eNOS) as well as the mechanism by which $\mathrm{NO}$ production was stimulated (cytokines and nerve growth factor vs. vasoactive pharmacological agents). Further studies are warranted to investigate these technical and/or biological differences with respect to the use of $\mathrm{NO}_{550}$.

In our study, we found that the probe has a unique extranuclear distribution but generates very weak signal intensity requiring the need for longer incubation and/or high probe concentrations compared to established fluorophores such as DAF-FM diacetate. In addition, we found that the reacted fluorescent product $\left(\mathrm{AZO}_{550}\right)$ is biochemically stable in primary vascular ECs, which indicates its potential as an imaging agent in longer kinetic studies of agents that may regulate vascular function. Interestingly, our comparative study of chemically synthesized $\mathrm{AZO}_{550}$-loaded cells with $\mathrm{NO}_{550}$-loaded cells indicated that $\mathrm{NO}_{550}$ has a unique and limited distribution pattern compared with its fluorescent product $\mathrm{AZO}_{550}$ (online suppl. fig. S8) suggesting that the nonfluorescent $\mathrm{NO}_{550}$ may not be able to effectively diffuse into some $\mathrm{NO}$-producing intracellular compartments.

Furthermore, our follow-up of $\mathrm{NO}_{550}$-loaded cells over time demonstrates that a progressively increasing fluorescence signal is observed (e.g. between 1 and $24 \mathrm{~h}$ ) in live cells, suggesting that unreacted probes in the culture may still be able to react with newly generated NO.

Treatment of cells with the NOS activator ACh increased fluorescence intensity whereas treatment with the inhibitors of NOS (L-NAME) or XOR (allopurinol) diminished the fluorescence signal, consistent with expected changes in NO synthesis [48-50]. The lack of complete inhibition of the fluorescence signal by L-NAME and allopurinol may reflect the presence of NO stores, such as nitrosothiol and nitrosoheme moieties [51-53]. Such stores have been shown to exist in ECs and would not be sensitive to transient inhibition by allopurinol or LNAME as in this study. Indeed, we demonstrated that the NOS-/XOR-insensitive fluorescent signal can be effec- 


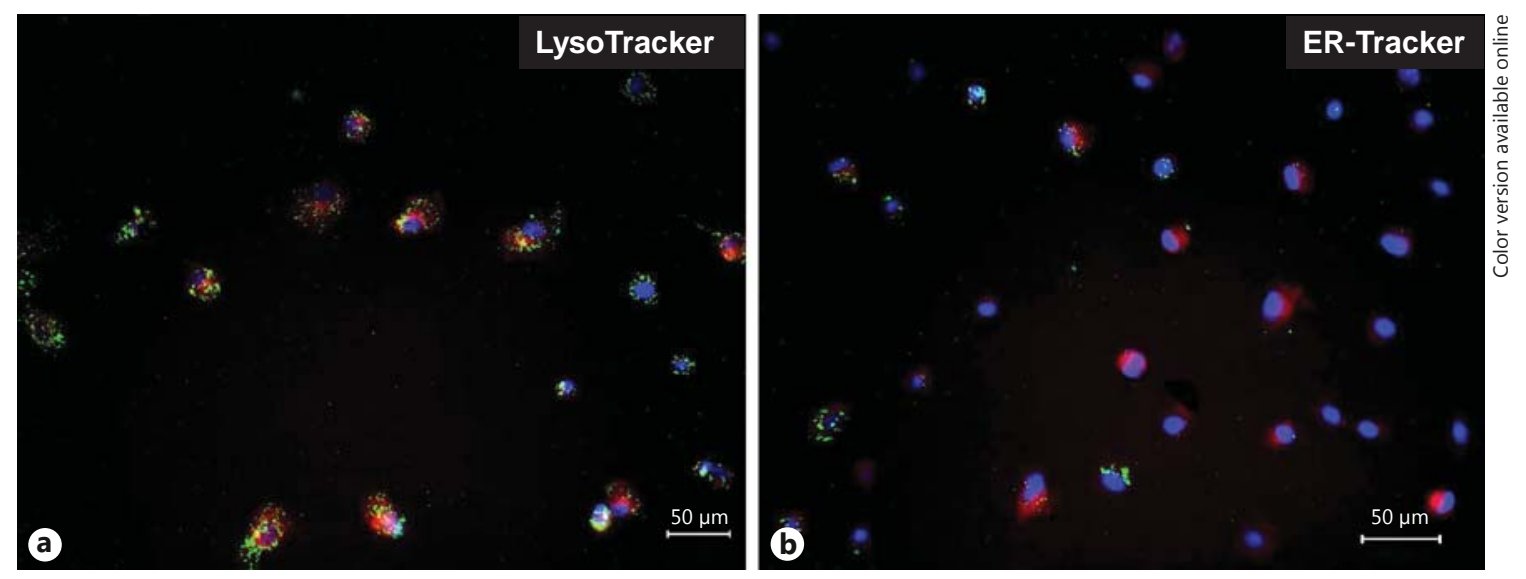

Fig. 6. Compartmentalization of $\mathrm{NO}_{550}$. HMVECs were costained with $\mathrm{NO}_{550}$ (green), Hoechst (blue) and LysoTracker (red; a) or ER-Tracker (red; b). Colors are shown online.
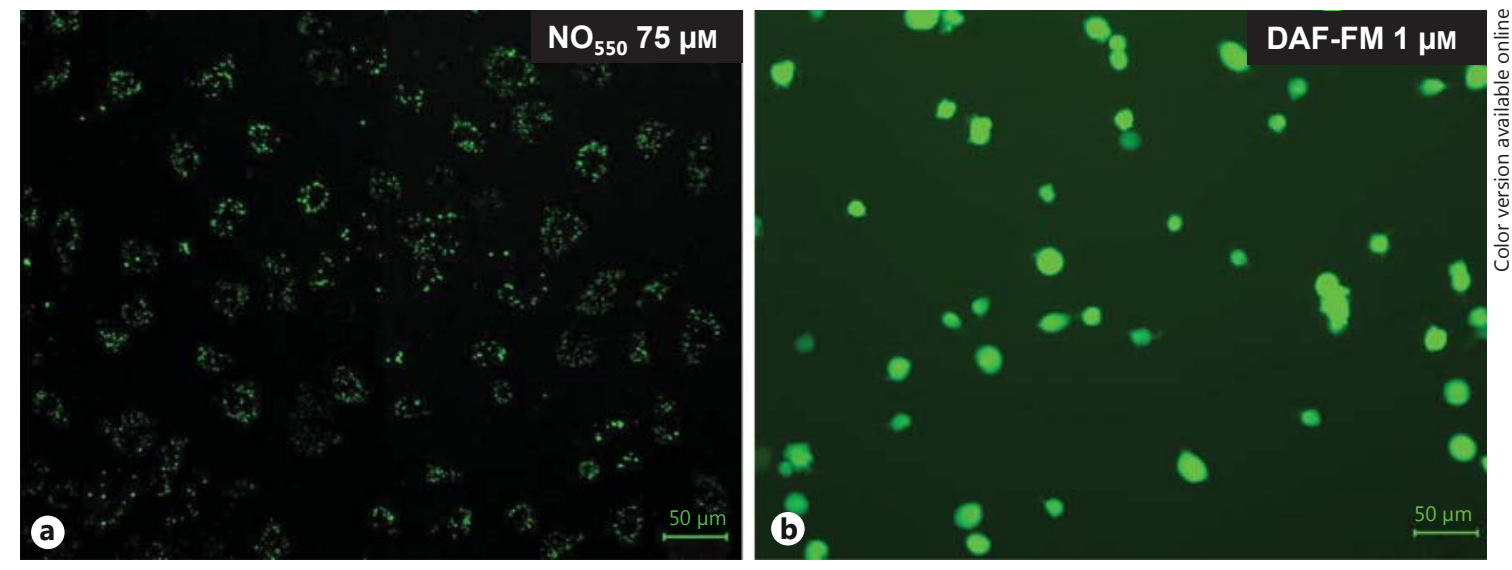

Fig. 7. Comparison of $\mathrm{NO}_{550}$ with DAF-FM diacetate. HMVECs were loaded with $\mathrm{NO}_{550}(75 \mu \mathrm{M}$; a) or DAF-FM diacetate $(1 \mu \mathrm{M} ; \mathbf{b})$. Images were captured $1 \mathrm{~h}$ after $\mathrm{NO}_{550}$ loading and $20 \mathrm{~min}$ after loading with DAF-FM diacetate. Excess DAF-FM diacetate probe was washed off in PBS ( $\mathrm{pH}=7.4)$. Colors are shown online.

tively eliminated when an NO scavenger is present. For example, the small molecule PTIO scavenges NO by forming a stoichiometric radial-radical interaction [44]. Cultured ECs generate less NO with ACh stimulation than with agents that activate the inducible isoform of NOS [54]. Indeed, our data show that induction of the inducible isoform of NOS using the cytokine TNF- $\alpha$ robustly stimulated NO production and enhanced the fluorescent signal.

Our comparison of $\mathrm{NO}_{550}$ to the commercially available and widely used fluorescent NO probe, DAF-FM diacetate, indicated that $\mathrm{NO}_{550}$ has some significant advantages. This probe provided minimal background outside cells and showed distinct cytoplasmic and perinuclear punctuate fractions without crossing the nuclear membrane. In contrast, DAF-FM diacetate displayed significant extracellular background and permeation into the nuclei, as demonstrated in a previous report using DAF-2 diacetate [39]. Since there is no concrete evidence that NO is physiologically present in the nuclei of human ECs, the presence of a signal with DAF-FM diacetate dye in the cell nuclei is likely a nonspecific reactivity of the dye. On the other hand, several reports have identified the existence of active eNOS in multiple extranuclear compartments in ECs, including in plasmalemmal caveolae, Golgi bodies [55], and the cytoskeleton [56, and the refer- 
Table 1. Comparison of fluorophore-based imaging agents for NO

\begin{tabular}{|c|c|c|c|c|c|c|}
\hline $\begin{array}{l}\text { Detection } \\
\text { agent }\end{array}$ & Limitation & $\begin{array}{l}\text { Turn ON } \\
\text { signal (fold) }\end{array}$ & $\begin{array}{l}\mathrm{Ex} / \mathrm{Em}, \\
\mathrm{nm}\end{array}$ & $\begin{array}{l}\text { Detection } \\
\text { limit, nM }\end{array}$ & pH dependency & Ref. \\
\hline DAF-2 & $\begin{array}{l}\text { Permeates into nuclei; high background; phenol } \\
\text { red, } \mathrm{Ca}^{2+} / \mathrm{Mg}^{2+} \text { interferences; photostability }\end{array}$ & $184^{\mathrm{a}}$ & $495 / 515$ & 5 & $\begin{array}{l}\text { Less efficient below pH } 7 \\
\text { and above } \mathrm{pH} 7.5\end{array}$ & $\begin{array}{l}28,39 \\
61,62\end{array}$ \\
\hline $\begin{array}{l}\text { DAN } \\
\text { reagent }\end{array}$ & $\begin{array}{l}\text { Not highly reactive to NO; inefficient at alkaline } \\
\text { pH; hemoglobin, phenol red and BSA interfere } \\
\text { with signal }\end{array}$ & ND & $375 / 415$ & $10-30$ & Effective at neutral $\mathrm{pH}$ & 63,64 \\
\hline DAR-4M & $\begin{array}{l}\text { DHA and } \mathrm{Ca}^{2+} \text { interfere with signal; high } \\
\text { background }\end{array}$ & 840 & $560 / 575$ & 7 & $\begin{array}{l}\text { No dependency above } \\
\text { pH } 4\end{array}$ & 30,61 \\
\hline DAF-FM & $\begin{array}{l}\text { Photobleaching; permeates into nuclei; } \\
\text { autofluorescence }\end{array}$ & 160 & $495 / 515$ & 3 & Effective above $\mathrm{pH} 6$ & $\begin{array}{l}46,65 \\
\text { this study }\end{array}$ \\
\hline DACs & Weak signal & 14 & $750 / 850$ & N/A & $\begin{array}{l}\text { Slightly sensitive to } \mathrm{pH} \\
\text { above } 6\end{array}$ & 36 \\
\hline SWNTs & $\begin{array}{l}\text { Extended probe incubation }(12 \mathrm{~h}) \text { prior to } \\
\text { imaging; oxidative species interfere with signal }\end{array}$ & ND & $658 / 850$ & 70 & $\begin{array}{l}\text { Only demonstrated at } \\
\text { neutral } \mathrm{pH}\end{array}$ & 38 \\
\hline QDs & $\begin{array}{l}\text { Not demonstrated in cells; weak signal; } \\
\text { excitation/emission overlap; low sensitivity }\end{array}$ & 10 & $595 / 595$ & 3,000 & Not reported & 37 \\
\hline $\mathrm{NO}_{550}$ & $\begin{array}{l}\text { Significant serum-binding; rapid elimination } \\
\text { after washing loaded cells; low hydrophilicity }\end{array}$ & 1,500 & $470 / 550$ & 30 & $\begin{array}{l}\text { No } \mathrm{pH} \text { dependency } \\
\text { between } 4.5 \text { and } 9\end{array}$ & $\begin{array}{l}39 \text {, } \\
\text { this study }\end{array}$ \\
\hline
\end{tabular}

ences therein]. Although $\mathrm{NO}_{550}$ has an advantage over other probes in that it provides a signal that is localized to compartments that are expected to generate NO, it does have some flaws. Its poor water solubility, low sensitivity (by comparison to DAF-FM i.e. 30 vs. 3 nM; table 1), and potential reactivity with oxidation products of $\mathrm{NO}$ such as nitrates $\left(\mathrm{NO}_{3}\right)$, nitrites $\left(\mathrm{NO}_{2}\right)$, peroxynitrite $\left(\mathrm{OONO}^{-}\right)$, nitrosoheme and/or nitrosothiols (R-SNO) in cells are weaknesses that may need to be addressed with secondgeneration analogues.

Interestingly, we also found that physiological (PBS; $\mathrm{pH}$ 7.4) rinsing of cells loaded with the $\mathrm{NO}_{550}$ probe resulted in immediate disappearance of the fluorescent signal from subcellular compartments. This rapid elimination of the signal by a simple wash step suggests that the probe might largely be localized in the caveolae. Caveolins are ubiquitously expressed membrane proteins known to form the caveola membrane of mammalian cells in order to allow internalization and trafficking of exogenous molecules independent of surface receptors. Caveolin-1 is primarily expressed in vascular smooth muscle cells, fibroblasts and ECs, and is well known to interact with eNOS and influence NO production [56-58].

This observation warrants further mechanistic studies to delineate the site(s) of interaction and precise subcellular compartmentalization of the $\mathrm{NO}_{550}$ probe. In the meantime, our colocalization study using cell-permeant organelle-specific dyes to label the lysosomes indicates that $\mathrm{NO}_{550}$ does not appear to be emitted from these acidic compartments. To our knowledge, there is no scientific evidence demonstrating the presence of NO in these vesicles in ECs under baseline conditions. In addition, our compartmentalization study of $\mathrm{NO}_{550}$ in conjunction with an ER-tracking dye caused progressively increasing cell death and reduced $\mathrm{NO}_{550}$-associated fluorescence intensity suggesting that either the active drug (gliben- 
clamide) conjugated to the ER-Tracker dye has impaired the ability of the cells to actively uptake $\mathrm{NO}_{550}$ probe [59] or ER stress, which is known to impair NO production, has been induced [60].

Finally, this probe might be useful for conducting large-scale kinetic studies to profile the effect of drugs on NO release and vascular function as well as for diagnostic use of NO-related diseases and for performing highthroughput drug screening in search of novel small molecules that regulate NO provided that the selectivity, hydrophobicity, serum binding, and brightness issues could be optimized by a series of organic chemical studies.

In conclusion, we have evaluated the utility of the $\mathrm{NO}_{550}$ probe in imaging $\mathrm{NO}$ produced by primary vascular ECs and ECs derived from PSCs. In addition, we demonstrated that $\mathrm{NO}_{550}$ is reasonably stable in cells and is able to discriminate changes in NO in response to treatment of cells with pharmacological agents that increase or reduce $\mathrm{NO}$ levels. Finally, we found that the $\mathrm{NO}_{550}$ probe has a unique distribution pattern in subcellular compartments that is limited to perinuclear areas compared to the commercially available DAF-FM diacetate probe.

\section{Acknowledgments}

The authors are grateful to the laboratory of Dr. Renee Reijo Pera at Stanford University for providing the dermal fibroblasts used in the study.

This work was supported in part by grants to J.P.C. from the NIH (RC2HL103400, 1U01HL100397, K12HL087746 and 1R01EY02060901A1), American Heart Association (AHA) (11IRG5180026), the Stanford SPARK Program and by the Tobacco-Related Disease Research Program of the University of California (18XT-0098). N.F.H. was supported by an NIH grant (R00HL098688). Y.T.G. was a recipient of the Stanford School of Medicine Dean's fellowship (1049528-149-KAVFB) and the Tobacco-Related Disease Research Program of the University of California (20FT-0090). He is currently supported by a K-award from the National Heart, Lung, and Blood Institute (grant 1K01HL118683-01).

\section{Disclosure Statement}

J.P.C. and Y.T.G. are inventors of a patent owned by Stanford University that protects the use of agents that modulate the NOS pathway for therapeutic use.

\section{References}

1 Furchgott RF, Zawadzki JV: The obligatory role of endothelial cells in the relaxation of arterial smooth muscle by acetylcholine. Nature 1980;288:373-376.

- 2 Ignarro LJ, Buga GM, Wood KS, Byrns RE, Chaudhuri G: Endothelium-derived relaxing factor produced and released from artery and vein is nitric oxide. Proc Natl Acad Sci USA 1987;84:9265-9269.

3 Palmer RM, Ferrige AG, Moncada S: Nitric oxide release accounts for the biological activity of endothelium-derived relaxing factor. Nature 1987;327:524-526.

-4 Tsao PS, Buitrago R, Chan JR, Cooke JP: Fluid flow inhibits endothelial adhesiveness. Nitric oxide and transcriptional regulation of VCAM-1. Circulation 1996;94:1682-1689.

5 Tsao PS, Lewis NP, Alpert S, Cooke JP: Exposure to shear stress alters endothelial adhesiveness. Role of nitric oxide. Circulation 1995;92:3513-3519.

-6 Tsao PS, Wang B, Buitrago R, Shyy JY, Cooke JP: Nitric oxide regulates monocyte chemotactic protein-1. Circulation 1997;96:934-940.

7 Radomski MW, Palmer RM, Moncada S: Endogenous nitric oxide inhibits human platelet adhesion to vascular endothelium. Lancet 1987;ii:1057-1058.

8 Stamler J, Mendelsohn ME, Amarante P, Smick D, Andon N, Davies PF, Cooke JP, Loscalzo J: $\mathrm{N}$-acetylcysteine potentiates platelet inhibition by endothelium-derived relaxing factor. Circ Res 1989;65:789-795.
\$9 Garg UC, Hassid A: Nitric oxide-generating vasodilators and 8-bromo-cyclic guanosine monophosphate inhibit mitogenesis and proliferation of cultured rat vascular smooth muscle cells. J Clin Invest 1989;83:1774-1777. 10 von der Leyen HE, Gibbons GH, Morishita R, Lewis NP, Zhang L, Nakajima M, Kaneda Y, Cooke JP, Dzau VJ: Gene therapy inhibiting neointimal vascular lesion: in vivo transfer of endothelial cell nitric oxide synthase gene. Proc Natl Acad Sci USA 1995;92:1137-1141.

11 Cooke JP, Singer AH, Tsao P, Zera P, Rowan RA, Billingham ME: Antiatherogenic effects of L-arginine in the hypercholesterolemic rabbit. J Clin Invest 1992;90:1168-1172.

12 Tanaka M, Sydow K, Gunawan F, Jacobi J, Tsao PS, Robbins RC, Cooke JP: Dimethylarginine dimethylaminohydrolase overexpression suppresses graft coronary artery disease. Circulation 2005;112:1549-1556.

$\checkmark 13$ Konishi H, Sydow K, Cooke JP: Dimethylarginine dimethylaminohydrolase promotes endothelial repair after vascular injury. J Am Coll Cardiol 2007;49:1099-1105.

14 Ghebremariam YT, Lependu P, Lee JC, Erlanson DA, Slaviero A, Shah NH, Leiper J, Cooke JP: Unexpected effect of proton pump inhibitors: elevation of the cardiovascular risk factor asymmetric dimethylarginine. Circulation 2013; 128:845-853.

15 Naruse K, Shimizu K, Muramatsu M, Toki Y, Miyazaki Y, Okumura K, Hashimoto H, Ito T: Long-term inhibition of NO synthesis pro- motes atherosclerosis in the hypercholesterolemic rabbit thoracic aorta. PGH2 does not contribute to impaired endothelium-dependent relaxation. Arterioscler Thromb 1994; 14:746-752.

16 Kuhlencordt PJ, Gyurko R, Han F, ScherrerCrosbie M, Aretz TH, Hajjar R, Picard MH, Huang PL: Accelerated atherosclerosis, aortic aneurysm formation, and ischemic heart disease in apolipoprotein E/endothelial nitric oxide synthase double-knockout mice. Circulation 2001;104:448-454.

17 Sydow K, Mondon CE, Schrader J, Konishi H, Cooke JP: Dimethylarginine dimethylaminohydrolase overexpression enhances insulin sensitivity. Arterioscler Thromb Vasc Biol 2008;28:692-697.

18 Duplain H, Burcelin R, Sartori C, Cook S, Egli M, Lepori M, Vollenweider P, Pedrazzini T, Nicod P, Thorens B, Scherrer U: Insulin resistance, hyperlipidemia, and hypertension in mice lacking endothelial nitric oxide synthase. Circulation 2001;104:342-345.

19 Schachinger V, Britten MB, Zeiher AM: Prognostic impact of coronary vasodilator dysfunction on adverse long-term outcome of coronary heart disease. Circulation 2000;101: 1899-1906.

20 Yeboah J, Crouse JR, Hsu FC, Burke GL, Herrington DM: Brachial flow-mediated dilation predicts incident cardiovascular events in older adults: the Cardiovascular Health Study. Circulation 2007;115:2390-2397. 
-21 Wilson AM, Shin DS, Weatherby C, Harada RK, Ng MK, Nair N, Kielstein J, Cooke JP: Asymmetric dimethylarginine correlates with measures of disease severity, major adverse cardiovascular events and all-cause mortality in patients with peripheral arterial disease. Vasc Med 2010;15:267-274.

-22 Malinski T, Mesaros S, Tomboulian P: Nitric oxide measurement using electrochemical methods. Methods Enzymol 1996;268:58-69.

-23 Nagano T, Yoshimura T: Bioimaging of nitric oxide. Chem Rev 2002;102:1235-1270.

24 Diab N, Schuhmann W: Electropolymerized manganese porphyrin/polypyrrole films as catalytic surfaces for the oxidation of nitric oxide. Electrochim Acta 2001;47:265-273.

25 Kikuchi K, Nagano T, Hayakawa H, Hirata Y, Hirobe M: Real time measurement of nitric oxide produced ex vivo by luminol- $\mathrm{H}_{2} \mathrm{O}_{2}$ chemiluminescence method. J Biol Chem 1993; 268:23106-23110.

-26 Seo EW, Han JH, Heo CH, Shin JH, Kim HM, Cho BR: A small-molecule two-photon probe for nitric oxide in living tissues. Chemistry 2012; 18:12388-12394.

-27 Jobgen WS, Jobgen SC, Li H, Meininger CJ, $\mathrm{Wu}$ G: Analysis of nitrite and nitrate in biological samples using high-performance liquid chromatography. J Chromatogr B Analyt Technol Biomed Life Sci 2007;851:71-82.

-28 Kojima H, Nakatsubo N, Kikuchi K, Kawahara S, Kirino $Y$, Nagoshi H, Hirata Y, Nagano T: Detection and imaging of nitric oxide with novel fluorescent indicators: diaminofluoresceins. Anal Chem 1998;70: 2446-2453.

-29 Kojima H, Sakurai K, Kikuchi K, Kawahara S, Kirino Y, Nagoshi H, Hirata Y, Akaike T, Maeda H, Nagano T: Development of a fluorescent indicator for the bioimaging of nitric oxide. Biol Pharm Bull 1997;20:12291232.

- 30 Kojima H, Hirotani M, Nakatsubo N, Kikuchi K, Urano Y, Higuchi T, Hirata Y, Nagano T: Bioimaging of nitric oxide with fluorescent indicators based on the rhodamine chromophore. Anal Chem 2001;73:1967-1973.

- 31 Heiduschka P, Thanos S: NO production during neuronal cell death can be directly assessed by a chemical reaction in vivo. Neuroreport 1998;9:4051-4057.

- 32 Gabe Y, Urano Y, Kikuchi K, Kojima H, Nagano T: Highly sensitive fluorescence probes for nitric oxide based on boron dipyrromethene chromophore - rational design of potentially useful bioimaging fluorescence probe. J Am Chem Soc 2004;126:3357-3367.

- 33 Gabe Y, Ueno T, Urano Y, Kojima H, Nagano $\mathrm{T}$ : Tunable design strategy for fluorescence probes based on 4-substituted BODIPY chromophore: improvement of highly sensitive fluorescence probe for nitric oxide. Anal Bioanal Chem 2006;386:621-626.

- 34 Lim MH, Xu D, Lippard SJ: Visualization of nitric oxide in living cells by a copper-based fluorescent probe. Nat Chem Biol 2006;2: 375-380.

\$35 Liu M, Ye Z, Wang G, Yuan J: Development of a novel europium(III) complex-based luminescence probe for time-resolved lumines- cence imaging of the nitric oxide production in neuron cells. Talanta 2012;99:951-958.

36 Sasaki E, Kojima H, Nishimatsu H, Urano Y, Kikuchi K, Hirata Y, Nagano T: Highly sensitive near-infrared fluorescent probes for nitric oxide and their application to isolated organs. J Am Chem Soc 2005;127:3684-3685.

37 Wang S, Han MY, Huang D: Nitric oxide switches on the photoluminescence of molecularly engineered quantum dots. J Am Chem Soc 2009;131:11692-11694.

- 38 Kim JH, Heller DA, Jin H, Barone PW, Song C, Zhang J, Trudel LJ, Wogan GN, Tannenbaum SR, Strano M: The rational design of nitric oxide selectivity in single-walled carbon nanotube near-infrared fluorescence sensors for biological detection. Nat Chem 2009;1: 473-481.

39 Yang Y, Seidlits SK, Adams MM, Lynch VM, Schmidt CE, Anslyn EV, Shear JB: A highly selective low-background fluorescent imaging agent for nitric oxide. J Am Chem Soc 2010;132:13114-13116.

40 National Institutes of Health, http://rsb.info. nih.gov/ij/docs/.

41 Huang NF, Fleissner F, Sun J, Cooke JP: Role of nitric oxide signaling in endothelial differentiation of embryonic stem cells. Stem Cells Dev 2010;19:1617-1626.

42 Rufaihah AJ, Huang NF, Jame S, Lee JC, Nguyen HN, Byers B, De A, Okogbaa J, Rollins M, Reijo-Pera R, Gambhir SS, Cooke JP: Endothelial cells derived from human iPSCS increase capillary density and improve perfusion in a mouse model of peripheral arterial disease. Arterioscler Thromb Vasc Biol 2011; 31:e72-e79.

43 Papapetrou EP, Sadelain M: Generation of transgene-free human induced pluripotent stem cells with an excisable single polycistronic vector. Nat Protoc 2011;6:12511273.

44 Akaike T, Yoshida M, Miyamoto Y, Sato K, Kohno M, Sasamoto K, Miyazaki K, Ueda S, Maeda H: Antagonistic action of imidazolineoxyl $\mathrm{N}$-oxides against endothelium-derived relaxing factor/.NO through a radical reaction. Biochemistry 1993;32:827-832.

45 Hogg N, Singh RJ, Joseph J, Neese F, Kalyanaraman B: Reactions of nitric oxide with nitronyl nitroxides and oxygen: prediction of nitrite and nitrate formation by kinetic simulation. Free Radic Res 1995;22:47-56.

46 Molecular Probes: Nitric oxide indicators: DAF-FM and DAF-FM diacetate. Product insert, 2001.

47 Balbatun A, Louka FR, Malinski T: Dynamics of nitric oxide release in the cardiovascular system. Acta Biochim Pol 2003;50:61-68.

48 Alef MJ, Vallabhaneni R, Carchman E, Morris SM Jr, Shiva S, Wang Y, Kelley EE, Tarpey MM, Gladwin MT, Tzeng E, Zuckerbraun BS: Nitrite-generated NO circumvents dysregulated arginine/NOS signaling to protect against intimal hyperplasia in SpragueDawley rats. J Clin Invest 2011;121:16461656.

49 Cooke JP, Ghebremariam YT: Dietary nitrate, nitric oxide, and restenosis. J Clin Invest 2011; 121:1258-1260.
50 Ichinose M, Sugiura H, Yamagata S, Koarai A, Tomaki M, Ogawa H, Komaki Y, Barnes PJ, Shirato K, Hattori T: Xanthine oxidase inhibition reduces reactive nitrogen species production in COPD airways. Eur Respir J 2003; 22:457-461.

51 Cooke JP, Tsao PS: Is NO an endogenous antiatherogenic molecule? Arterioscler Thromb 1994; 14:653-655.

52 Gow AJ, Chen Q, Hess DT, Day BJ, Ischiropoulos $\mathrm{H}$, Stamler JS: Basal and stimulated protein S-nitrosylation in multiple cell types and tissues. J Biol Chem 2002;277:9637-9640.

$53 \mathrm{Ng}$ ES, Cheng ZJ, Ellis A, Ding H, Jiang Y, Li Y, Hollenberg MD, Triggle CR: Nitrosothiol stores in vascular tissue: modulation by ultraviolet light, acetylcholine and ionomycin. Eur J Pharmacol 2007;560:183-192.

54 Cocks TM, Angus JA, Campbell JH, Campbell GR: Release and properties of endotheliumderived relaxing factor (EDRF) from endothelial cells in culture. J Cell Physiol 1985;123: 310-320.

- 55 Sessa WC, Garcia-Cardena G, Liu J, Keh A, Pollock JS, Bradley J, Thiru S, Braverman IM, Desai KM: The Golgi association of endothelial nitric oxide synthase is necessary for the efficient synthesis of nitric oxide. J Biol Chem 1995;270:17641-17644.

56 Michel T, Feron O: Nitric oxide synthases: which, where, how, and why? J Clin Invest 1997; 100:2146-2152.

57 Williams TM, Lisanti MP: The caveolin proteins. Genome Biol 2004;5:214.

58 Feng Y, Venema VJ, Venema RC, Tsai N, Caldwell RB: VEGF induces nuclear translocation of Flk-1/KDR, endothelial nitric oxide synthase, and caveolin-1 in vascular endothelial cells. Biochem Biophys Res Commun 1999;256:192-197.

59 Ferrer R, Atwater I, Omer EM, Goncalves AA, Croghan PC, Rojas E: Electrophysiological evidence for the inhibition of potassium permeability in pancreatic beta-cells by glibenclamide. QJ Exp Physiol 1984;69:831-839.

60 Gotoh T, Mori M: Nitric oxide and endoplasmic reticulum stress. Arterioscler Thromb Vasc Biol 2006;26:1439-1446.

61 Chatton JY, Broillet MC: Detection of nitric oxide production by fluorescent indicators. Methods Enzymol 2002;359:134-148.

62 Leikert JF, Rathel TR, Muller C, Vollmar AM, Dirsch VM: Reliable in vitro measurement of nitric oxide released from endothelial cells using low concentrations of the fluorescent probe 4,5-diaminofluorescein. FEBS Lett 2001;506: 131-134.

63 Misko TP, Schilling RJ, Salvemini D, Moore WM, Currie MG: A fluorometric assay for the measurement of nitrite in biological samples. Anal Biochem 1993;214:11-16.

64 Miles AM, Chen Y, Owens MW, Grisham MB: Fluorometric determination of nitric oxide. Methods 1995;7:40-47.

65 Itoh Y, Ma FH, Hoshi H, Oka M, Noda K, Ukai Y, Kojima H, Nagano T, Toda N: Determination and bioimaging method for nitric oxide in biological specimens by diaminofluorescein fluorometry. Anal Biochem 2000; 287:203-209. 